\title{
In Vitro Bile Acid Binding of Mustard Greens, Kale, Broccoli, Cabbage and Green Bell Pepper Improves with Sautéing Compared with Raw or Other Methods of Preparation*
}

\section{Talwinder S. Kahlon, Rebecca R. Milczarek, Mei-Chin M. Chiu}

Processed Foods Research Unit, Western Regional Research Center, United States Department of Agriculture-Agricultural Research Service, Albany, USA.

Email: Talwinder.Kahlon@ars.usda.gov

Received April 24 $4^{\text {th }}, 2012$; revised May 24 $4^{\text {th }}, 2012$; accepted June $2^{\text {nd }}, 2012$

\begin{abstract}
Bile acid binding potential of foods and food fractions has been related to lowering the risk of heart disease and that of cancer. Steam cooking has been observed to significantly improve bile acid binding of green/leafy vegetables. It was hypothesized that other cooking methods could further improve the bile acid binding of various vegetables. Sautée cooking resulted in vitro bile acid binding measured on a dry matter basis relative to cholestyramine of $14 \%$ for mustard greens and kale, $9 \%$ for broccoli and collard greens, and $6 \%$ for cabbage, and $5 \%$ for green bell pepper. These results point to the significantly different $(\mathrm{P} \leq 0.05)$ health promoting potential of mustard greens $=$ kale $>$ broccoli $=$ collard greens $>$ cabbage $>$ green bell pepper. Sautéing significantly improved in vitro bile acid binding of mustard greens, kale, broccoli, cabbage and green bell pepper compared with steaming, boiling or raw (uncooked). Collard greens exhibited significantly higher bile acid binding by steaming compared with sautéing, boiling or raw. Data suggest that the cooking method with most heath promoting potential for mustard greens, kale, broccoli, cabbage and green bell pepper should be sautéing. Steaming should be used for collard greens as the cooking method. These green/leafy vegetables, when consumed regularly after sautéing, would promote a healthy lifestyle and have the potential to lower the risk of premature degenerative diseases.
\end{abstract}

Keywords: In Vitro; Bile Acid Binding; Mustard Greens; Kale; Broccoli; Cabbage; Green Bell Pepper and Collard Greens; Sautéing; Steaming; Boiling

\section{Introduction}

Along with consuming lower calories from saturated fat and animal products, vegetarians and those consuming vegetables as a major portion of their daily diet are at a lower risk of coronary heart disease and cancer $[1,2]$. Vegetables are a good source of dietary fiber, antioxidants, phytonutrients, provitamins, polyphenols and minerals. The USDA Food and Nutrition Information Center, Food Guide Plate (http://www.choosemyplate.gov/) recommends that $50 \%$ of daily calories should come from vegetables and fruits. In order to maintain desirable body weight, one needs to consume dark leafy colorful vegetables and low fat food products along with keeping an active lifestyle [3]. Some of the vegetables listed by the

"USDA is an equal opportunity provider and employer. Mention of trade names or commercial products in this report is solely for the purpose of providing specific information and does not imply recommendation or endorsement by the US Department of Agriculture.
USDA food guide include mustard greens, kale, broccoli, cabbage, collard greens and bell pepper. Isothiocyanates of the cruciferous vegetables in the brassica family have been shown to protect against various types of cancers [4-7]. Sulforaphane, indole-3-carbinol, glucaric acid and other isothiocyanates are antioxidants and potent stimulators of natural detoxifying enzymes in the body. These compounds are believed to be responsible for the lowered risk of atherosclerosis and cancer [8,9]. Toxic metabolites in the gut and secondary bile acids increase the risk of colorectal cancer [10]. Atherosclerosis and cancer are two leading causes of death and disability in the developed world and are increasing rapidly in the developing world [11]. These are major human nutrition problems and are preventable with diet and a physically active lifestyle. The healthful, cholesterol-lowering (atherosclerosis amelioration) or detoxification of harmful metabolites (cancer prevention) potential of food fractions 
could be predicted by evaluating their in vitro bile acid binding, based on positive correlations found between in vitro and in vivo studies showing that cholestyramine (a bile acid binding, cholesterol lowering drug) binds bile acids and cellulose does not [12-15]. Bile acids are acidic steroids synthesized in the liver from cholesterol. After conjugation with glycine or taurine, they are secreted into the duodenum. Bile acids are actively reabsorbed by the terminal ileum and undergo an enterohepatic circulation [16]. Binding of bile acids and increasing their fecal excretion has been hypothesized as a possible mechanism by which food fractions lower cholesterol [17-19]. Bile acids are needed for the absorption of dietary fat from the GI tract. Dietary fat is a precursor of cholesterol synthesis in the body. By binding bile acids, food fractions prevent their reabsorption and stimulate plasma and liver cholesterol conversion to additional bile acids [20-23]. The US Food and Drug Administration and UK-Joint Health Claim Initiative have allowed label health claims on food products containing oats for their blood cholesterol lowering potential $[24,25]$. Excretion of toxic metabolites and secondary bile acids could lower the risk of cancer [10]. Bile acid binding of grain fractions, ready to eat cereals, various dry beans has been observed to be proportional to their dry matter content [26-29]. Steam cooking collard greens, kale, mustard greens, broccoli, green bell pepper and cabbage significantly improved in vitro bile acid binding compared with the values obtained for these vegetables in uncooked form [30,31].

The hypothesis of this study was to evaluate relative enhanced bile acid binding of mustard greens (Brassica juncea), kale (Brassica oleracea acephala), collard greens (Brassica oleracea acephala), broccoli (Brassica oleracea italica), cabbage (Brassica oleracea capitala), and green bell pepper (Capsicum annuum) by sautéing, steaming or boiling as determined by their bile acid binding on equal dry matter basis, with a bile acid mixture under human duodenal physiological $\mathrm{pH}$ of 6.3 .

\section{Materials and Methods}

Fresh vegetables were purchased from a local grocery super market early in the morning at 6:30 a.m. as being displayed out of the delivery boxes. All the vegetables were purchased at the same time. The vegetables were washed, trimmed and sliced or chopped. Mustard greens, kale and collard greens were cut crosswise into $0.75-1.0$ inch pieces; broccoli into 1.0 - 2.0 inch florets; cabbage into 1.0 - 1.5 inch pieces; and green bell pepper into 0.5 inch. Composition of the vegetables tested is given in Table 1.

$500 \mathrm{~g}$ of fresh vegetable samples were boiled (10 to 14 $\min$ ) in an 8 quart stainless steel pot with sufficient water to cover the vegetables, stream cooked (10 to $20 \mathrm{~min}$.) in the same pot with a steam inset, or sautéed (fried lightly in small amount of unsalted butter, $28.3 \mathrm{~g}$; while turning over frequently) in a 14 inch flat bottom wok (Hot Point Model No. R B526 H3WW, General Electric Co Louisville, KY) setting 5 on a scale of 11 (LO, 1 - 9, HI) for 15 - $20 \mathrm{~min}$ to the tenderness as ready to be eaten. Cooking time was determined based on the evaluation consensus of the laboratory personnel. Unsalted butter was chosen as the common fat source used in sautéeing in most home kitchens. All the cooked vegetables were dried to a constant weight at $68^{\circ} \mathrm{C}$ for $48 \mathrm{hr}$ in a steam heated forced air food dryer (Proctor 062, Proctor \& Schwartz, Inc, Horsham, PA, USA). Dry samples were ground in a Braun coffee grinder (Gillette Commercial, Boston, MA) to pass a $0.4 \mathrm{~mm}$ screen. Dry matter in sautéed samples was corrected after removing excess fat by hexane. Total dietary fiber (TDF) of the test samples was determined by AOAC method 985.29 [32].

Samples were analyzed for nitrogen by method 990.03 [33], with a Virio Macro Elemental Analyser (Elementar Analysen systeme $\mathrm{GmbH}$, Hanau, Germany), crude fat with petroleum ether by accelerated solvent extractor (ASE 350 Dionex Corp., Bannockburn, IL), ash by method 942.05 [33], and moisture by method 935.29 [33]. Nitrogen to protein conversion factor used for all the vegetables was 6.25 . Cholestyramine, a bile acid binding anionic resin (a drug that lowers cholesterol and binding bile acids), was the positive control treatment, cellulose (a non bile acid binding fiber) was the negative control. Both were obtained from Sigma (St. Louis, MO).

\subsection{In Vitro Bile Acid Binding Procedure}

In vitro bile acid binding procedure was a modification of that by Camire et al. [34], as previously reported [26]. The stock bile acid mixture was formulated, with glycocholic bile acids providing $75 \%$ and taurine-conjugated bile acids $25 \%$ of the bile acids, based on the composition of the human bile $[35,36]$. This mixture contained glycocholic acid $(9 \mathrm{mmol} / \mathrm{l})$, glycochenocholic acid (9 $\mathrm{mmol} / \mathrm{l})$, glycodeoxycholic acid $(9 \mathrm{mmol} / \mathrm{l})$, taurocholic acid $(3 \mathrm{mmol} / \mathrm{l})$, taurochenocholic acid $(3 \mathrm{mmol} / \mathrm{l})$ and taurodeoxycholic acid $(3 \mathrm{mmol} / \mathrm{l})$ in $\mathrm{pH} 6.3,0.1 \mathrm{M}$ phosphate buffer. This stock solution of $36 \mathrm{mmol} / \mathrm{l}$ was stored at $-20^{\circ} \mathrm{C}$ and diluted to the working solution just prior to each assay $(0.72 \mu \mathrm{mol} / \mathrm{mL})$ for vegetable and cellulose samples; $(2.88 \mu \mathrm{mol} / \mathrm{mL})$ for cholestyramine based upon the binding capacity of $100 \mathrm{mg}$ dry matter. Eight replicate incubations, consisting of six substrates with bile acid mixture, one substrate blank without bile acid mixture and one bile acid mixture without the substrate, were run for each of the six vegetables and two control treat- 
ments. Each treatment replicate was weighed into $16 \times$ $150 \mathrm{~mm}$ glass, screw-capped tube. Samples were digested in $1 \mathrm{~mL} 0.01 \mathrm{~N} \mathrm{HCl}$ for one hour in a $37^{\circ} \mathrm{C}$ shaker bath. After this acidic incubation which simulated gastric digestion, the sample $\mathrm{pH}$ was adjusted to 6.3 with $0.1 \mathrm{~mL}$ of $0.1 \mathrm{~N} \mathrm{NaOH}$. To each test sample was added $4 \mathrm{~mL}$ of bile acid mixture working solution. A phosphate buffer (4 mL, 0.1 M, pH 6.3) was added to the individual substrate blanks. After the addition of $5 \mathrm{~mL}$ of porcine pancreatin $(5 \times, 10 \mathrm{mg} / \mathrm{mL}$, in a $0.1 \mathrm{M}$ phosphate buffer, $\mathrm{pH}$ 6.3 , providing amylase, protease and lipase for digestion of samples), tubes were incubated for one hour in a $37^{\circ} \mathrm{C}$ shaker bath. Mixtures were transferred to $10 \mathrm{~mL}$ centrifuge tubes (Oak Ridge 3118 - 0010, Nalgene, Rochester, $\mathrm{NY}$ ) and centrifuged at 99,000 $\mathrm{g}$ in a $75-\mathrm{Ti}$ rotor at $39 \mathrm{~K}$ rpm for $18 \mathrm{~min}$ at $25^{\circ} \mathrm{C}$ in an ultracentrifuge (model L-60, Beckman, Palo Alto, CA). Supernatant was removed into a second set of labeled tubes. An additional $5 \mathrm{~mL}$ of phosphate buffer was used to rinse out the incubation tube and added to the centrifuge tube, which was vortexed and centrifuged as before. Supernatant was removed and combined with the previous supernatant. Aliquots of pooled supernatant were frozen at $-20^{\circ} \mathrm{C}$ for bile acids analysis. Bile acids were analyzed by the Trinity Biotech bile acids procedure No. 450-A (Trinity Biotech Distribution, St. Louis, MO) using a Ciba-Corning Express Plus analyzer (Polestar Labs, Inc., Escondido, CA). Each sample was analyzed in triplicate. Values were determined from a standard curve obtained by analyzing Trinity Biotech bile acid calibrators (No. 450-11) at $5,25,50,100$ and $200 \mu \mathrm{mol} / \mathrm{L}$. Individual blank substrates were subtracted, and bile acid concentrations were corrected based on the mean recoveries of bile acid mixture (positive blank).

\subsection{Statistical Analysis}

Data are presented as means \pm SEM. Before accepting analysis of variance results, Lavene's test was used to check for homogeneity of variances among treatments. Since variances were considered homogenous from test results, analysis of variance was used to test for significant differences among treatments. Dunnett's one-tailed test was computed with treatments compared to cholestyramine as a positive control and compared to cellulose as a negative control. For comparing non-control treatments to each other, Tukey's test for comparison of all possible pairs of means was used. SAS Proc GLM was used for all statistical analysis and testing [37,38]. A value of $(P \leq 0.05)$ was considered the criterion of significance.

\section{Results}

The composition, dietary fiber (total, soluble and insolu- ble), percent dry matter, cooking time for boiled, steamed and sautéed mustard greens, kale, collard greens, broccoli, cabbage, and green bell pepper is given in Table 1 . Cooking time ranged from $10-20 \mathrm{~min}$ for the various vegetables tested. The dry matter content was highest for steam cooked kale (11\%), and lowest for mustard greens (5\%). Both cellulose and cholestyramine were considered as $100 \%$ total dietary fiber [15].

On an equal dry matter (DM) basis, bile acid binding was significantly higher for cholestyramine and significantly lower for cellulose than raw (uncooked) and cooked (boiled, steamed and sautéed) vegetables. The bile acid binding values for sautéed mustard greens, kale, broccoli, cabbage and green bell pepper were significantly $(\mathrm{P} \leq$ 0.05 ) higher compared to values for these vegetables raw, boiled or steam cooked (Table 2). Only collard greens had significantly higher bile acid binding values for steaming than for sautéing, boiling or raw. Steam cooking mustard greens, kale, collard greens, and cabbage resulted in significantly higher bile acid binding compared with boiling or raw.

The mean binding value of cellulose (negative control) was deducted from all treatments and the positive control values. Assigning a bile acid binding value of $100 \%$ to cholestyramine, the relative bile acid binding values on a dry matter basis for the test samples when sautéed were $14 \%$ for mustard greens and kale; $9 \%$ for broccoli and collard greens, $6 \%$ for cabbage and 5\% for green bell pepper (Table 3). The relative health promoting potential based on bile acid binding on a dry matter basis was mustard greens $=$ kale $>$ collard greens $=$ broccoli $>$ cabbage $>$ green bell pepper. Only steamed collard greens had significantly higher (9\%) bile acid binding compared to values for this vegetable in raw, boiled or sautéed form.

For vegetables cooked by various methods calculated as eaten, the highest bile acid binding value was observed for sautéed kale $(169 \mu \mathrm{mol} / 100 \mathrm{~g}$ cooked as eaten $)$ and the lowest value was for steamed or raw green bell pepper $(15 \mu \mathrm{mol} / 100 \mathrm{~g}$ as eaten) (Table 4). The relative healthful potential was sautéed kale $>$ steamed collard greens $>$ steamed or sautéed broccoli $=$ sautéed mustard greens $>$ sautéed cabbage $>$ sautéed green bell pepper.

Table 5 presents calculated bile acid binding relative to cholestyramine for $100 \mathrm{~g}$ cooked vegetables as is based using $13.86 \%$ of cholestyramine (Table 3 ) for $169.41 \mathrm{umol} / 100 \mathrm{~g}$ as is (Table 4) for sautéed kale. Highest bile acid binding values were for sautéed kale and lowest for green bell pepper and cabbage.

\section{Discussion}

Boiling vegetables resulted in significant $(10 \%-35 \%)$ 
Table 1. Composition and cooking time of raw, boiled, steamed, sautéed; mustard greens, kale, collard greens, broccoli, cabbage, and green bell pepper, dry matter (DM) basis ${ }^{\mathrm{a}}$.

\begin{tabular}{|c|c|c|c|c|c|c|c|c|c|}
\hline Source & TDF & SDF & IDF & Protein & Fat & Minerals & Carbohydrt & DM & Cooking Time \\
\hline & \multicolumn{6}{|c|}{$\begin{array}{c}\mathrm{DM} \\
\%\end{array}$} & \multicolumn{2}{|c|}{$\%$} & $\min$ \\
\hline \multicolumn{10}{|l|}{ Mustard Green } \\
\hline Raw (uncooked) & 30.65 & 3.90 & 26.76 & 39.66 & 4.14 & $16.98^{\mathrm{c}}$ & 42.32 & 5.54 & 0 \\
\hline Boiled & 36.3 & 1.97 & 34.34 & 42.34 & 6.66 & $10.06^{\mathrm{i}}$ & 42.90 & 3.63 & 12 \\
\hline Steamed & 23.58 & 1.97 & 21.6 & 41.85 & 6.46 & $15.43^{\mathrm{e}}$ & 38.61 & 4.70 & 20 \\
\hline Sautéed & 33.82 & 1.47 & 32.36 & 36.19 & 19.02 & $16.06^{\mathrm{d}}$ & 31.94 & 4.37 & 20 \\
\hline \multicolumn{10}{|l|}{ Kale } \\
\hline Raw (uncooked) & 37.13 & 5.42 & 31.7 & 37.83 & 6.64 & $14.89^{\mathrm{f}}$ & 43.10 & 9.94 & 0 \\
\hline Boiled & 46.08 & 10.56 & 35.52 & 37.21 & 7.61 & $8.77^{\mathrm{jk}}$ & 48.24 & 8.53 & 14 \\
\hline Steamed & 36.15 & 9.63 & 26.52 & 37.61 & 7.45 & $12.78^{\mathrm{h}}$ & 44.16 & 11.17 & 15 \\
\hline Sautéed & 40.73 & 9.12 & 31.61 & 36.79 & 12.88 & $12.69^{\mathrm{h}}$ & 39.82 & 10.3 & 18 \\
\hline \multicolumn{10}{|l|}{ Collard Greens } \\
\hline Raw (uncooked) & 36.59 & 7.34 & 29.25 & 30.41 & 5.95 & $19.62^{\mathrm{a}}$ & 45.82 & 11.32 & 0 \\
\hline Boiled & 43.87 & 8.38 & 35.49 & 28.88 & 5.86 & $13.78^{\mathrm{g}}$ & 53.19 & 7.24 & 10 \\
\hline Steamed & 38.62 & 10.30 & 28.32 & 28.92 & 4.84 & $17.83^{\mathrm{b}}$ & 49.93 & 9.71 & 15 \\
\hline Sautéed & 32.15 & 8.09 & 24.06 & 27.14 & 11.45 & $17.88^{\mathrm{b}}$ & 45.53 & 7.59 & 15 \\
\hline \multicolumn{10}{|l|}{ Broccoli } \\
\hline Raw (uncooked) & 21.15 & 5.14 & 26.01 & 39.92 & 3.92 & $8.94^{\mathrm{j}}$ & 49.69 & 9.35 & 0 \\
\hline Boiled & 40.52 & 9.77 & 30.76 & 41.54 & 7.00 & $6.25^{\mathrm{n}}$ & 47.24 & 6.63 & 10 \\
\hline Steamed & 28.17 & 8.45 & 19.72 & 41.25 & 5.54 & $8.40^{\mathrm{kl}}$ & 47.08 & 8.92 & 10 \\
\hline Sautéed & 31.11 & 6.33 & 24.78 & 39.02 & 1010 & $8.18^{1}$ & 45.66 & 6.65 & 15 \\
\hline \multicolumn{10}{|l|}{ Cabbage } \\
\hline Raw (uncooked) & 23.62 & 3.88 & 19.74 & 17.22 & 1.18 & $6.64^{\mathrm{m}}$ & 76.18 & 7.83 & 0 \\
\hline Boiled & 33.94 & 9.67 & 24.27 & 18.52 & 2.19 & $5.60^{\circ}$ & 74.96 & 5.21 & 10 \\
\hline Steamed & 23.34 & 8.16 & 15.17 & 18.03 & 1.97 & $6.67^{\mathrm{m}}$ & 74.50 & 7.98 & 10 \\
\hline Sautéed & 25.88 & 7.47 & 18.41 & 17.60 & 10.79 & $6.12^{\mathrm{n}}$ & 67.18 & 6.92 & 18 \\
\hline \multicolumn{10}{|l|}{ Green Bell Pepper } \\
\hline Raw (uncooked) & 27.28 & 9.67 & 17.62 & 20.63 & 2.35 & $5.75^{\circ}$ & 73.26 & 5.35 & 0 \\
\hline Boiled & 31.71 & 11.78 & 19.93 & 21.92 & 3.21 & $4.69^{\mathrm{q}}$ & 72.18 & 4.13 & 14 \\
\hline Steamed & 26.13 & 9.64 & 16.49 & 22.09 & 3.04 & $5.20^{\mathrm{p}}$ & 71.68 & 5.26 & 15 \\
\hline Sautéed & 24.63 & 9.11 & 15.51 & 21.40 & 11.2 & $5.50^{\circ}$ & 65.23 & 4.05 & 18 \\
\hline
\end{tabular}

${ }^{a}$ Nitrogen to protein factor used for all the vegetables was 6.25. Carbohydrate $=100-$ (Protein + fat + minerals). Total dietary fiber (TDF); Soluble dietary fiber (SDF); Insoluble dietary fiber (IDF). Mineral values with different superscript letters differ significantly (P $\leq 0.05)$. Pooling data for cooking methods showed no significant effect on minerals or soluble dietary fiber levels between the cooking methods tested.

loss in mineral content compared with raw vegetables, and steam cooking resulted in $0 \%-14 \%$ mineral loss (Table 1); similar observations have been previously reported [39]. Various cooking methods resulted in an increase in soluble dietary fiber (SDF) in kale $(80 \%)$, collard greens (58\%), broccoli (22\%) and cabbage (217\%), whereas it was unchanged in green bell pepper and decreased in mustard greens $(-46 \%)$. The data suggest that IDF was converted to SDF by cooking kale, collard greens, broccoli and cabbage. Similar increases in SDF and reductions in IDF by cooking vegetables have been previously reported [40]. Pooling data for cooking methods showed no significant effect on minerals or soluble dietary fiber levels among the cooking methods tested.

Consistent with previous reports [31], steam cooking resulted in significantly higher bile acid binding compared with that of raw mustard greens, kale, collard greens, broccoli and cabbage. On a dry matter basis rela- 
Table 2. Bile acid binding of mustard greens, kale, collard greens, broccoli, cabbage and green bell pepper as influenced by cooking methods, $\mu \mathrm{mol} / \mathbf{1 0 0 m g}$ dry matter ${ }^{\mathrm{a}}$.

\begin{tabular}{lcccc}
\hline \multirow{2}{*}{ Vegetable } & \multicolumn{3}{c}{ Cooking Method } \\
\cline { 2 - 4 } & Raw & Boiled & Steamed & Sautéed \\
\hline Mustard Greens & $1.01 \pm 0.01^{\mathrm{c}}$ & $1.01 \pm 0.01^{\mathrm{c}}$ & $1.34 \pm 0.03^{\mathrm{b}}$ & $1.69 \pm 0.03^{\mathrm{a}}$ \\
Kale & $1.27 \pm 0.01^{\mathrm{d}}$ & $1.33 \pm 0.01^{\mathrm{c}}$ & $1.46 \pm 0.01^{\mathrm{b}}$ & $1.64 \pm 0.02^{\mathrm{a}}$ \\
Collard Greens & $1.04 \pm 0.01^{\mathrm{b}}$ & $0.98 \pm 0.02^{\mathrm{b}}$ & $1.16 \pm 0.06^{\mathrm{a}}$ & $1.05 \pm 0.02^{\mathrm{b}}$ \\
Broccoli & $0.66 \pm 0.01^{\mathrm{c}}$ & $0.80 \pm 0.02^{\mathrm{b}}$ & $0.84 \pm 0.01^{\mathrm{b}}$ & $1.13 \pm 0.03^{\mathrm{a}}$ \\
Cabbage & $0.21 \pm 0.01^{\mathrm{d}}$ & $0.41 \pm 0.02^{\mathrm{c}}$ & $0.53 \pm 0.01^{\mathrm{b}}$ & $0.76 \pm 0.02^{\mathrm{a}}$ \\
Green Bell Pepper & $0.28 \pm 0.02^{\mathrm{c}}$ & $0.49 \pm 0.02^{\mathrm{b}}$ & $0.30 \pm 0.02^{\mathrm{c}}$ & $0.64 \pm 0.03^{\mathrm{a}}$ \\
\hline
\end{tabular}

${ }^{a}$ Values are mean \pm SEM; values within rows with different superscript letters are significantly different $(\mathrm{P} \leq 0.05), 100-102 \mathrm{mg}$ dry matter used in each incubation; $\mathrm{n}=6$, each bile acid analysis was conducted in triplicate.

Table 3. Bile acid binding of mustard greens, kale, collard greens, broccoli, cabbage and green bell pepper as influenced by cooking methods, cholestyramine, $\%$ (dm basis) ${ }^{\mathrm{a}}$.

\begin{tabular}{lcccc}
\hline \multirow{2}{*}{ Vegetable } & \multicolumn{3}{c}{ Cooking Method } \\
\cline { 2 - 5 } & Raw & Boiled & Steamed & Sautéed \\
\hline Mustard Greens & $8.14 \pm 0.08^{\mathrm{c}}$ & $8.15 \pm 0.09^{\mathrm{c}}$ & $11.18 \pm 0.25^{\mathrm{b}}$ & $14.26 \pm 0.26^{\mathrm{a}}$ \\
Kale & $10.48 \pm 0.12^{\mathrm{d}}$ & $11.09 \pm 0.06^{\mathrm{c}}$ & $12.18 \pm 0.13^{\mathrm{b}}$ & $13.86 \pm 0.21^{\mathrm{a}}$ \\
Collard Greens & $8.45 \pm 0.08^{\mathrm{b}}$ & $7.90 \pm 0.14^{\mathrm{b}}$ & $9.48 \pm 0.56^{\mathrm{a}}$ & $8.56 \pm 0.15^{\mathrm{b}}$ \\
Broccoli & $5.04 \pm 0.12^{\mathrm{c}}$ & $6.29 \pm 0.15^{\mathrm{b}}$ & $6.69 \pm 0.07^{\mathrm{b}}$ & $9.25 \pm 0.23^{\mathrm{a}}$ \\
Cabbage & $0.98 \pm 0.09^{\mathrm{d}}$ & $2.83 \pm 0.17^{\mathrm{c}}$ & $3.87 \pm 0.13^{\mathrm{b}}$ & $5.91 \pm 0.19^{\mathrm{a}}$ \\
Green Bell Pepper & $1.65 \pm 0.15^{\mathrm{c}}$ & $3.52 \pm 0.18^{\mathrm{b}}$ & $1.85 \pm 0.15^{\mathrm{c}}$ & $4.86 \pm 0.31^{\mathrm{a}}$ \\
\hline
\end{tabular}

${ }^{a}$ Values are mean \pm SEM; values within rows with different superscript letters are significantly different $(\mathrm{P} \leq 0.05), 100-102 \mathrm{mg}$ dry matter used in each incubation; $n=6$, each bile acid analysis was conducted in triplicate.

Table 4. Bile acid binding of mustard greens, kale, collard greens, broccoli, cabbage and green bell pepper as influenced by cooking methods, $\mu \mathrm{mol} / \mathbf{1 0 0 g}$ as is ${ }^{\mathrm{a}}$.

\begin{tabular}{lcccc}
\hline \multirow{2}{*}{ Vegetable } & \multicolumn{3}{c}{ Cooking Method } \\
\cline { 2 - 5 } & Raw & Boiled & Steamed & Sautéed \\
\hline Mustard Greens & $55.75 \pm 0.47^{\mathrm{c}}$ & $36.55 \pm 0.35^{\mathrm{d}}$ & $63.20 \pm 1.29^{\mathrm{b}}$ & $73.87 \pm 1.27^{\mathrm{a}}$ \\
Kale & $125.96 \pm 1.33^{\mathrm{c}}$ & $113.87 \pm 0.58^{\mathrm{d}}$ & $162.72 \pm 1.56^{\mathrm{b}}$ & $169.41 \pm 2.36^{\mathrm{a}}$ \\
Collard Greens & $117.72 \pm 1.00^{\mathrm{a}}$ & $70.90 \pm 1.12^{\mathrm{b}}$ & $112.22 \pm 6.07^{\mathrm{a}}$ & $79.92 \pm 1.23^{\mathrm{b}}$ \\
Broccoli & $61.68 \pm 1.25^{\mathrm{b}}$ & $53.01 \pm 1.10^{\mathrm{c}}$ & $75.28 \pm 0.72^{\mathrm{a}}$ & $75.13 \pm 1.71^{\mathrm{a}}$ \\
Cabbage & $16.09 \pm 0.75^{\mathrm{d}}$ & $21.47 \pm 1.00^{\mathrm{c}}$ & $42.18 \pm 1.11^{\mathrm{b}}$ & $52.41 \pm 1.48^{\mathrm{a}}$ \\
Green Bell Pepper & $15.03 \pm 0.90^{\mathrm{c}}$ & $20.24 \pm 0.82^{\mathrm{b}}$ & $15.97 \pm 0.87^{\mathrm{c}}$ & $25.89 \pm 1.39^{\mathrm{a}}$ \\
\hline
\end{tabular}

${ }^{a}$ Values are mean \pm SEM; values within rows with different superscript letters are significantly different $(\mathrm{P} \leq 0.05), 100-102 \mathrm{mg}$ dry matter used in each incubation; $n=6$, each bile acid analysis was conducted in triplicate.

tive to cholestyramine the observed bile acid binding values for steam cooked vegetables (12\% for kale, $11 \%$ for mustard greens, $9 \%$ for collard greens, $7 \%$ for broccoli and $4 \%$ for cabbage) are very similar to those reported previously [31]. Data suggest that the healthful potential of these vegetables is very consistent and/or the bile acid binding assay is quite reliable. The most healthful potential observed herein was for sautéed mustard greens $=$ sautéed kale $>$ steamed collard greens $=$ sautéed broccoli $>$ sautéed cabbage $>$ sautéed green bell pepper. Fat used in sauteing would not affect the bile acid binding as it has been previously observed that bile acid binding is not related to the fat content [15].

The bile acid binding of various grain fractions, readyto-eat cereals and beans has been related to their dry matter content [23-26]. Evaluating the health promoting properties (cholesterol lowering and excretion of toxic metabolites) of vegetables cooked by various methods as 
Table 5. Bile acid binding of mustard greens, kale, collard greens, broccoli, cabbage and green bell pepper as influenced by cooking methods, cholestyramine, $\% / 100 \mathrm{~g}$ as is ${ }^{\mathrm{a}}$.

\begin{tabular}{lcccc}
\hline \multirow{2}{*}{ Vegetable } & \multicolumn{3}{c}{ Cooking Method } \\
\cline { 2 - 4 } & Raw & Boiled & Steamed & Sautéed \\
\hline Mustard Greens & $4.56 \pm 0.04^{\mathrm{c}}$ & $2.99 \pm 0.03^{\mathrm{d}}$ & $5.17 \pm 0.11^{\mathrm{b}}$ & $6.04 \pm 0.10^{\mathrm{a}}$ \\
Kale & $10.31 \pm 0.11^{\mathrm{c}}$ & $9.32 \pm 0.05^{\mathrm{d}}$ & $13.31 \pm 0.13^{\mathrm{b}}$ & $13.86 \pm 0.19^{\mathrm{a}}$ \\
Collard Greens & $9.63 \pm 0.08^{\mathrm{a}}$ & $5.80 \pm 0.09^{\mathrm{b}}$ & $9.18 \pm 0.50^{\mathrm{a}}$ & $6.54 \pm 0.10^{\mathrm{b}}$ \\
Broccoli & $5.05 \pm 0.10^{\mathrm{b}}$ & $4.34 \pm 0.09^{\mathrm{c}}$ & $6.16 \pm 0.06^{\mathrm{a}}$ & $6.15 \pm 0.14^{\mathrm{a}}$ \\
Cabbage & $1.32 \pm 0.06^{\mathrm{d}}$ & $1.76 \pm 0.08^{\mathrm{c}}$ & $3.45 \pm 0.09^{\mathrm{b}}$ & $4.29 \pm 0.12^{\mathrm{a}}$ \\
Green Bell Pepper & $1.23 \pm 0.07^{\mathrm{c}}$ & $1.66 \pm 0.07^{\mathrm{b}}$ & $1.31 \pm 0.07^{\mathrm{c}}$ & $2.12 \pm 0.11^{\mathrm{a}}$ \\
\hline
\end{tabular}

${ }^{a}$ Values are mean \pm SEM; values within rows with different superscript letters are significantly different $(\mathrm{P} \leq 0.05), 100-102 \mathrm{mg}$ dry matter used in each incubation; $\mathrm{n}=6$, each bile acid analysis was conducted in triplicate.

they are normally consumed would be appropriate by testing their bile acid binding on dry matter basis. The differences in bile acid binding between various vegetables tested may relate to their phytonutrients (antioxidants, chlorophyll, flavonoids, sulforaphane, indole-3carbinol, glucaric acid and isothiocyanates, micro elements, tannins), hyrophobicity or active binding sites. The effect of drying and grinding vegetable on bile acid binding cannot be determined in the study reported herein. It is assumed that such an effect would be insignificant. However, evaluation of this effect is of interest and would be the subject of future investigations. Laboratory animal and human studies are warranted to assess the in vivo cholesterol lowering and cancer prevention effects of these vegetables prepared by sautéing or steaming.

A relative bile acid binding value of 5\% - 9\% on dry matter basis for oat bran, oat bran ready to eat cereals and barley fractions (cereals with US-FDA and UK-Joint Health Claim initiative) approved for a label health claim for lowering cholesterol have been reported [24,25]. Bile acid binding of $5 \%-14 \%$ in steamed or sautéed mustard greens, kale, collard greens, broccoli, cabbage and green bell pepper on dry matter basis is very encouraging. Data suggest that the green leafy vegetables tested have the potential to qualify for US and UK label health claims.

The bile acid binding value for steamed vegetables aseaten per $100 \mathrm{~g}$ were significantly different among vegetables tested. The highest bile acid binding values were sautéed kale (14\%), steamed collard greens (9\%), steamed or sautéed broccoli $(6 \%)$, sautéed mustard greens, cabbage and green bell pepper $(6 \%, 4 \%$ and $2 \%$ respectively).

In conclusion, relative to cholestyramine, the in vitro bile acid binding on a dry matter basis was $14 \%$ for sautéed mustard greens and kale; $9 \%$ for steamed or sautéed collard greens; and $9 \%, 6 \%$ and $5 \%$ for sautéed broccoli, cabbage and green bell pepper, respectively. These results point to the significant differences in health pro- moting potential of sautéed mustard greens $=$ kale $>$ collard greens $=$ broccoli $>$ cabbage $>$ green bell pepper as indicated by their bile acid binding on DM basis. Sautéing should be the cooking method of choice for the mustard greens, kale, broccoli, cabbage and green bell pepper. In the case of collard greens, steaming should be preferred. In case lowering fat content in diet is advised, steam cooking all the vegetables tested would be desirable. The hypothesis was proved that sautéing further improved the bile acid binding of several vegetables over steam cooking. Atherosclerosis and cancer are leading public health and nutrition research problems that are preventable by appropriate diet and lifestyle modifications. These green/leafy vegetables, when consumed regularly after steam cooking or sautéing, would lower the risk of premature degenerative diseases, advance positive human nutrition outcomes and improve public health.

\section{Acknowledgements}

The expert statistical assistance of Linda C. Whitehand, Consulting Statistician, WRRC, USDA-ARS, Albany, CA is greatly appreciated. This study was supported by USDA-ARS base funds.

\section{REFERENCES}

[1] T. J. Key, G. E. Fraser, M. Thorogood, P. N. Appleby, V. Beral, G. Reeves, M. L. Burr, J. Chang-Claude, R. Frentzel-Beyme, J. W. Kuzma, J. Mann and K. McPherson, "Mortality in Vegetarians and Nonvegetarians: Detailed Findings from a Collaborative Analysis of 5 Prospective Studies," American Journal of Clinical Nutrition, Vol. 70, No. 3, 1999, pp. 516S-524S

[2] T. J. Key, P. N. Appleby, E. A. Spencer, R. C. Travis, N. E. Allen, M. Thorogood and J. I. Mann, "Cancer Incidence in British Vegetarians," British Journal of Cancer, Vol. 101, No. 1, 2009, pp. 192-197. doi: $10.1038 /$ sj.bjc. 6605098

[3] USDA, Center for Nutrition Policy and Promotion, "Dietary Guidelines for Americans," 2010. 
http://www.choosemyplate.gov/

[4] K. A. Steinmetz and J. D. Potter, "Vegetables, Fruits, and Cancer Prevention: A Review," Journal of American Dietetic Association, Vol. 96, No. 10, 1996, pp. 1027-1039. doi:10.1016/S0002-8223(96)00273-8

[5] Y. Zhang, P. Talalay, C. G. Cho and G. H. Posner, "A Major Inducer of Anticarcinogenic Protective Enzymes from Broccoli: Isolation and Elucidation of Structure," Proceedings National Academy of Sciences, Vol. 89, No. 6, 1992, pp. 2399-2403. doi:10.1073/pnas.89.6.2399

[6] Y. Zhang, T. W. Kensler and C. G. Cho, "Anticarcinogenic Activities of Sulforaphane and Structurally Related Synthetic Norbornyl Isothiocyanates," Proceedings $\mathrm{Na}$ tional Academy of Sciences, Vol. 91, No. 8, 1994, pp. 3147-3150.

[7] J. W. Fahey, Y. Zhang and P. Talalay, "Broccoli Sprouts: An Exceptionally Rich Source of Inducers of Enzymes that Protect against Chemical Carcinogens," Proceedings National Academy of Sciences, Vol. 94, No. 19, 1997, pp. 10367-10372. doi:10.1073/pnas.94.19.10367

[8] B. N. Ames, M. K. Shigenaga and T. M. Hagen, "Oxidants, Antioxidants, and the Degenerative Diseases of Aging," Proceedings National Academy of Sciences, Vol. 90, No. 17, 1993, pp. 7915-7922. doi:10.1073/pnas.90.17.7915

[9] S. S. Hecht, "Chemoprevention of Cancer by Isothiocyanates, Modifiers of Carcinogen Metabolism," Journal of Nutrtion, Vol. 129, No. 3786, 1999, pp. 768S-774S.

[10] V. Costarelli, T. J. Key, P. N. Appleby, D. S. Allen, I. S. Fentiman and T. A. Sanders, "A Prospective Study of Serum Bile Acid Concentrations and Colorectal Cancer Risk in Post-Menopausal Women on the Island of Guernsey," British Journal of Cancer, Vol. 86, No. 11, 2002, pp. 1741-1744. doi:10.1038/sj.bjc.6600340

[11] C. D. Mathers, A. D. Lopez and C. J. L. Murray, "The Burden of Disease and Mortality by Condition: Data, Methods, and Results," In: A. D. Lopez, C. D. Mathers, M. Ezzati, D. T. Jamison and C. J. L. Murray, Eds., Global Burden of Disease and Risk Factors, Oxford University Press, New York, 2001.

[12] K. E. Suckling, G. M. Benson, B. Bond, A. Gee, A. Glen, C. Haynes and B. Jackson, "Cholesterol Lowering and Bile Acid Excretion in the Hamster with Cholestyramine Treatment," Atherosclerosis, Vol. 89, No. 2, 1991, pp. 183-190. doi:10.1016/0021-9150(91)90059-C

[13] T. Nakamura and Y. Matsuzawa, "Drug Treatment of Yperlipoproteinemia: Bile Acid-Binding Resins," Nippon Rinsho, Vol. 52, 1994, pp. 3266-3270.

[14] B. P. Daggy, N. C. O’Connell, G. R. Jerdack, B. A. Stinson and K. D. Setchell, "Additive Hypocholesterolemic Effect of Psyllium and Cholestyramine in the Hamster: Influence on Fecal Sterol and Bile Acid Profiles," Journal Lipid Research, Vol. 38, 1997, pp. 491-502.

[15] T. S. Kahlon and F. I. Chow, "In Vitro Binding of Bile Acids by Rice Bran, Oat Bran, Wheat Bran and Corn Bran," Cereal Chemistry, Vol. 77, No. 4, 2000, pp. 518521. doi:10.1094/CCHEM.2000.77.4.518
[16] A. F. Hofmann, "The Enterohepatic Circulation of Bile Acids in Man," Clinical Gastroenterology, Vol. 6, No. 1, 1977, pp. 3-24.

[17] H. C. Trowell, "Refined Foods and Disease," Burkitt and Trowell, Eds., Academic Press, London, 1975, pp. 195226.

[18] E. K. Lund, J. M. Gee, J. C. Brown, P. J. Wood and I. T. Johnson, "Effect of Oat Gum on the Physical Properties of the Gastrointestinal Contents and on the Uptake of D-Galactose and Cholesterol by Rat Small Intestine in Vitro," British Journal of Nutrition, Vol. 62, No. 1, 1989, pp. 91-101. doi:10.1079/BJN19890010

[19] J. W. Anderson and A. E. Siesel, "Hypocholesterolemic Effects of Oat Products," In: I. Furda and C. J. Brine, Eds., New Developments in Dietary Fiber: Physiological, Physiochemical, and Analytical Aspects, Plenum Press, New York, 1990, pp. 17-36.

[20] M. A. Eastwood and D. Hamilton, "Studies on the Adsorption of Bile Acids to Non-Absorbed Components of Diet," Biochimica Biophysica Acta, Vol. 152, 1968, pp. 165-173.

[21] J. Balmer and D. V. Zilversmit, "Effect of Dietary Roughage on Cholesterol Absorption, Cholesterol Turnover and Steroid Excretion in the Rat," Journal of Nutrition, Vol. 104, 1974, pp. 1319-1328.

[22] D. Kritchevsky and J. A. Story, "Binding of Bile Salts in Vitro by Nonnutritive Fiber," Journal of Nutrition, Vol. 104, 1974, pp. 458-462.

[23] S. M. Potter, "Soy Protein and Cardiovascular Disease: The Impact of Bioactive Components in Soy," Nutrition Reviews, Journal of Nutrition, Vol. 56, 1998, pp. 231235.

[24] US Food and Drug Administration, "FDA Final Rule for Federal Labeling: Health Claims; Oats and Coronary Heart Disease," Federal Register, Journal of Nutrition, Vol. 62, 1997, pp. 3584-3681.

[25] Joint Health Claims Initiative, "Final Report on Generic Health Claim for Oats and Reduction of Blood Cholesterol," 2004. http://www.jhci.org.uk/approv/oats.htm

[26] T. S. Kahlon and C. L. Woodruff, "In Vitro Binding of Bile Acids By Rice Bran, Oat Bran, Barley and $\beta$-Glucan Enriched Barley," Cereal Chemistry, Vol. 80, No. 3, 2003, pp. 260-263. doi:10.1094/CCHEM.2003.80.3.260

[27] T. S. Kahlon and C. L. Woodruff, "In Vitro Binding of Bile Acids by Various Ready to Eat Breakfast Cereals," Cereal Foods World, Vol. 48, 2003, pp. 73-75.

[28] T. S. Kahlon and Q. Shao, "In Vitro Binding of Bile Acids by Soy Bean (Glycine Max), Black Eye Bean (Vigna unguiculata), Garbanzo (Cicer arietinum) and Lima Bean (Phaseolus lunatus)," Food Chemistry, Vol. 86, No. 3, 2004, pp. 435-440. doi:10.1016/j.foodchem.2003.09.018

[29] T. S. Kahlon, G. E. Smith and Q. Shao, "In Vitro Binding of Bile Acids by Kidney Bean (Phaseolus vulgaris), Black Gram (Vigna mungo), Bengal Gram (Cicer arietinum) and Moth Bean (Phaseolus aconitifolins)," Food Chemistry, Vol. 90, No. 1-2, 2005, pp. 241-246.

doi:10.1016/j.foodchem.2004.03.046 
[30] T. S. Kahlon and G. E. Smith, "In Vitro Binding of Bile Acids by Spinach, Kale, Brussels sprouts, Broccoli, Mustard Greens, Peppers Green, Cabbage and Collards," Food Chemistry, Vol. 100, No. 4, 2007, pp. 1531-1536. doi:10.1016/j.foodchem.2005.12.020

[31] T. S. Kahlon, M. M. Chiu and M. Chapman, "Steam Cooking Significantly Improves in Vitro Bile Acid Binding of Collard Greens, Kale, Mustard Greens, Broccoli, Green Bell Pepper and Cabbage," Nutrition Research, Vol. 28, No. 6, 2008, pp. 351-357. doi:10.1016/j.nutres.2008.03.007

[32] AOAC, "Official Methods of Analysis of the Association of Official Analytical Chemists," 17th Edition, Arlington, 2000, pp. 78E-80E.

[33] AOAC, "Official Methods of Analysis of the Association of Official Analytical Chemists," 15th Edition, Arlington, 1990, pp. 70-75.

[34] M. E. Camire, J. Zhao and D. A. Violette, "In Vitro Binding of Bile Acids by Extruded Potato Peels," Journal of Agriculture and Food Chemistry, Vol. 41, No. 12, 1993, pp. 2391- 2394.

[35] M. C. Carey and D. M. Small, "The Characteristics of Mixed Micellar Solutions with Particular Reference to
Bile," American Journal Medicine, Journal of Nutrition, Vol. 49, 1970, pp. 590-608.

[36] S. S. Rossi, J. L. Converse and A. F. Hoffman, "High Pressure Liquid Chromatography Analysis of Conjugated Bile Acids in Human Bile: Simultaneous Resolution of Sulfated and Unsulfated Lithocholyl Amidates and the Common Conjugated Bile Acids," Journal of Lipid Research, Journal of Nutrition, Vol. 28, No. 5, 1987, pp. 589-595.

[37] R. G. D. Steel and J. H. Torrie, "Principles and Procedures of Statistics," McGraw-Hill, New York, 1960.

[38] SAS Institute Inc., "SAS Online Doc 9.1.3 Carey," 2004.

[39] E. W. Murphy, P. E. Criner and B. C. Gray, "Comparisons of Methods for Calculating Retentions of Nutrients in Cooked Foods," Journal of Agriculture and Food Chemistry, Vol. 23, No. 6, 1975, pp. 1153-1157. doi:10.1021/jf60202a021

[40] F. Khanum, S. Swamy, K. R. S. Krishna, K. Santhanam and K. R. Vishwanathan, "Dietary Fiber Content of Commonly Fresh and Cooked Vegetables Consumed in India," Plant Foods for Human Nutrition, Vol. 55, No. 3, 2000, pp. 207-218. doi:10.1023/A:1008155732404

\section{Abbreviations}

TDF: Total dietary fiber

IDF: Insoluble dietary fiber

SDF: Soluble dietary fiber

DM: Dry matter

SEM: Standard error of mean 